\title{
EVALUASI KUALITAS HIDUP PASIEN DIABETES MELITUS TIPE 2 DENGAN ANTIDIABETIK ORAL DI RUMAH SAKIT HARAPAN DAN DO'A KOTA BENGKULU
}

\author{
'Dian Handayani, ${ }^{2}$ Dwi Dominica, ${ }^{3}$ Reza Pertiwi, ${ }^{4}$ Feby R.A. Putri, ${ }^{5}$ Tya \\ Chalifatul, ${ }^{6}$ Dhea Ananda
}

1,2,3,4,5,6 Program Studi Sarjana Farmasi, Universitas Bengkulu, Bengkulu

\section{Info Article}

Submitted :

21 Juni 2021

\section{Revised :}

25 November 2021

\section{Accepted :}

1 Desember 2021

\section{Corresponding Author :}

Dian Handayani

Email :

apotekerdian25@gmail.com

\section{ABSTRAK}

Diabetes mellitus termasuk penyakit kronis yang tidak dapat disembuhkan secara total. Salah satu kunci untuk menilai keberhasilan terapi DM yaitu melalui peningkatan kualitas hidup pasien yang bisa diukur dengan kuesioner DQLCTQ (Diabetes Quality of Life Clinical Trial Quessionnaire). Penelitan ini bertujuan untuk mengetahui kualitas hidup pasien diabetes melitus tipe 2 dengan antidiabetik oral di Rumah Sakit Harapan dan Do'a Kota Bengkulu berdasar faktor pola terapi yang diterima pasien, jenis obat yang digunakan, dan karakteristik responden. Penelitian ini merupakan penelitian observasional analitik dengan desain Cross Sectional dengan pengambilan data pasien secara concurrent. Penelitian dilakukan di Rumah Sakit Harapan dan Do'a Kota Bengkulu. Sampel penelitian ini berjumlah 98 pasien DM tipe 2 yang melakukan kontrol ke rumah sakit ketika penelitian berlangsung dan memperoleh obat antidiabetik oral dan bersedia mengisi kuesioner DQLCTQ. Hasil penelitian menunjukkan bahwa tidak terdapat pengaruh antara faktor karakterisktik responden terhadap kualitas hidup. Skor kualitas hidup pasien yang mendapatkan akarbose, metformin, dan sulfonilurea, masingmasing adalah 61,$0 ; 61,3$ dan 61,4 . Hasil uji statistik dengan ANOVA $(p<0,05)$ menunjukkan bahwa tidak terdapat perbedaan yang signifikan antara ketiga kelompok pasien tersebut $(p=0,812)$. Pasien dengan pengobatan ADO tunggal memiliki skor kualitas hidupnya 64,0 sedangkan pasien dengan pengobatan ADO kombinasi memiliki skor kualitas hidupnya 62,3. Perbedaan ini berdasarkan hasil uji statistika dengan Independent sample t-test menunjukkan bahwa tidak terdapat perbedaan signifikan antara kedua kelompok tersebut $(p=0,134)$.

Kata kunci: Diabetes mellitus tipe 2, terapi antidiabetik oral, kualitas hidup, kuesioner DQLCTQ
Access this article

\section{ABSTRACT}

Diabetes mellitus is a chronic disease that can not be completely cured. Included in the key success of diabetes mellitus therapy is the efforts to increase patient's quality of life using the Diabetes Quality of Life Clinical Trial Quessionnaire (DQLCTQ) questionnaire. This purpose of this study was to determinate the quality of life of 


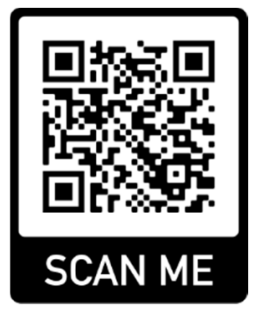

patients with type 2 diabetes mellitus with oral antidiabetic at Harapan and Do'a Hospital, Bengkulu City based on patient's characteristics, drug groups, and therapy pattern.. This study is an observational analytic cross sectional design. Data collection was done by interview and review of patient's medical record. This study was conducted in the Harapan dan Do'a Hospital, Bengkulu City. The number of samples in this study were 98 patients with type 2 diabetes mellitus who received oral antidiabetic therapy willing to fill out the DQLCTQ questionnaire. The results showed that the patients chacarteristics had no effect on the quality of life. Quality of life scores of patients receiving acarbose, metformin and sulfonylure were 61,$0 ; 61,3$ dan 61,4 respectively. The results of statistic tests with ANOVA showed that there were no significant differences between the three groups of patients $(p=0.812)$. Patients taking single ADO therapy had a QoL score of 64,0 while patients those taking combination ADO therapy had a QoL score of 62,3 . Independent sample t-test showed that those score was not significantly different $(p=0,134)$.

Keywords: Diabetes mellitus type 2, antidiabetic oral therapy, quality of life, DQLCTQ quessionnaire

\section{PENDAHULUAN}

DM (Diabetes Melitus) termasuk penyakit kelainan metabolik heterogen yang ditunjukkan dengan adanya hiperglikemia. Kondisi tersebut berhubungan dengan sistem metabolisme protein, lemak, serta karbohidrat yang tidak normal sehingga memicu penyakit kronis yang kompleks yakni gangguan neuropatik, makrovaskuler, dan mikrovaskuler (Dipiro, 2016). Diabetes melitus tipe 2 dibandingkan dengan diabetes tipe lain adalah penyakit yang berprevalensi paling tinggi 90\% dari seluruh kasus diabetes yang ada (ADA, 2018).

Prevalensi pasien diabetes di Indonesia saat ini berada pada urutan keenam sebanyak 10,3 milyar pada tahun 2017 serta diperkirakan pada tahun 2045 akan terus mengalami peningkatan sebanyak 16,7 milyar (Cho et al, 2018). Di lain hal untuk penyakit tidak menular menunjukkan kecenderungan yang terus mengalami peningkatan. Berdasarkan Riset Kesehatan Dasar terdapat peningkatan kasus penyakit tidak menular seperti penyakit sendi, stroke, hipertensi, dan diabetes. Diperkirakan kasus tersebut akan terus mengalami peningkatan (Kemenkes, 2017).

Salah satu kunci keberhasilan terapi DM yakni melalui peningkatan kualitas hidup (Triplit et al, 2005). Penggunaan obat antidiabetik dalam jangka panjang dapat mempengaruhi kualitas hidup pasien. Pengendalian awal pasien DM tipe 2 pada dasarnya tanpa menggunakan insulin, tetapi cukup dengan pemberian antidiabetik oral baik tunggal mapun kombinasi.Namun dalam keadaan tertentu juga bisa diberikan terapi insulin untuk pasien DM tipe 2 (Anonim, 2006). Pengobatan menggunakan antidiabetik oral bertujuan untuk mengendalikan kadar gula dalam darah melalui cara kerjanya masing-masing, namun hal ini juga bisa 
memicu efek samping berupa hipoglikemia, mual muntah, dan sebagainya sehingga dapat mempengaruhi kualitas hidup pasien.

Antidiabetik oral yang diresepkan di RSHD Kota Bengkulu meliputi golongan akarbose, metformin, dan sulfonilurea. Penelitian yang dilakukan oleh Rafika (2011) memaparkan karakteristik responden seperti pekerjaan, pendidikan, status pernikahan, lama menderita DM, umur, dan gender memberi pengaruh terhadap kualitas hidup pasien, akan tetapi tidak ada perbedaan kualitas hidup pasien yang memperoleh terapi pengobatan ADO kombinasi maupun yang memperoleh terapi ADO tunggal, serta tidak terdapat perbedaan kualitas hidup antara pasein yang memperoleh pengobatan sulfonilurea, akarbose, serta metformin.

Dalam studi pengembangan dan validasi kuesioner kualitas hidup pada pasien diabetes, DQLCTQ menjelaskan bahwa pasien diabetes melitus dengan gangguan psikologis dapat berpengaruh terhadap kontrol metabolisme oleh karena itu terjadi penurunan kualitas hidup. Domain kepuasan pribadi, kesehatan mental, tekanan kesehatan, dan kepuasan pengobatan bisa mengendalikan metabolisme yang memicu adanya perubahan klinis pada pasien diabetes melitus (Shen,dkk, 2019). Berdasarkan hal tersebut, maka perlu dilakukan evaluasi terhadap kualitas hidup pasien diabetes mellitus tipe 2 di poliklinik penyakit dalam RSHD Kota Bengkulu yang diterapi dengan antidiabetik oral berdasarkan faktor karakteristik responden, jenis obat yang digunakan, dan pola terapi yang diterima pasien.

\section{METODE PENELITIAN}

Jenis penelitian ini merupakan penelitian observasional analitik dengan desain Cross Sectional dengan pengambilan data pasien secara concurrent (Lies Mustaf, 2015), yaitu pengumpulan data dengan melakukan wawancara kepada pasien DM tipe 2 dan mengisi kuesioner Diabetes Quality of Life Clinical Trial Quessionnaire (DQLCTQ) bersamaan dengan pengumpulan data rekam medis pasien. Instrumen penelitian yang digunakan untuk mengukur kualitas hidup pasien menggunakan kuesioner Diabetes Quality of Life Clinical Trial Quessionnaire (DQLCTQ) (Shen, et al, 1999). Penelitian dilakukan di Rumah Sakit Harapan dan Do'a Kota Bengkulu. Jumlah sampel dalam penelitian ini adalah 98 pasien diabetes mellitus tipe 2 yang mendapat terapi antidiabetik oral. Metode pengambilan sampel dilakukan dengan metode purposive sampling, yaitu teknik pengambilan sampel berdasarkan kriteria inklusi (Sugioyono, 2016).

Kriteria inklusi meliputi pasien dengan kondisi sadar, bersedia menjadi responden, pasien rawat jalan di poli penyakit dalam RSHD Kota Bengkulu dengan diagnosa DM tipe 2, perempuan dan laki-laki, non geriatri ( $\leq 60$ tahun) serta geriatri ( $\geq 60$ tahun), dengan atau tanpa komplikasi, dan memperoleh ADO baik kombinasi atau tunggal. Kriteria eksklusi meliputi wanita hamil dan menyusui, catatan medis yang tidak lengkap, dan tidak bersedia terlibat hingga akhir penelitian.

Analisis data terdiri dari:

\section{Perhitungan Data Kuesioner}


Nilai kuesioner dihitung

memanfaatkan rumus berikut:

100(rata-rata-1) = nilai untuk domain

Nilai paling tinggi-1

Total nilai $=$ Rerata

Total item

(Rafika, 2011)

\section{Karakteristik}

Responden

Penelitian dan Kualitas Hidup

Karakteristik subyek penelitian dianalisis berdasarkan jumlah (persentase) dan rata-rata kualita hidup masing-masing kelompok karakeristik subyek menggunakan uji statistika independent sample t-test.

\section{Kualitas Hidup Berdasarkan Terapi Pengobatan}

a) Penentuan skor kualitas hidup subyek penelitian DM tipe 2 yang mendapat terapi metformin, sulfonilurea, dan acarbose dinilai dengan menghitung rata-rata total kualitas hidup dan rata-rata dari masing-masing domain. Untuk mengetahui perbedaan kualitas hidup dari ketiga kelompok digunakan uji One way Annova.

b) Perhitungan skor kualitas hidup responden penelitian DM tipe 2 dengan terapi kombinasi dan tunggal dinilai dengan menghitung total rata-rata kualitas hidup dan rata-rata dari setiap domainnya. Uji independent sample t-test digunakan untuk melihat perbedaan kualitas hidup kedua kelompok.

\section{HASIL DAN PEMBAHASAN}

Pada penelitian ini terdapat 98 subyek penelitian pasien DM tipe 2 .
Gambaran demografi responden penelitian diuraikan berikut:

\section{Usia}

Usia pasien yang menderita diabetes melitus tipe 2 di RSHD Kota Bengkulu sebagian besar terjadi pada kelompok usia kurang dari 60 tahun sebesar 59 pasien (60,2\%). Dan kelompok usia lebih dari 60 tahun sebesar 39 pasien (39,8\%). Namun, lain halnya dengan penelitian yang dilakukan Adikusuma W, dkk (2018) yang menyebutkan bahwa sebagian besar penderita diabetes mellitus tipe 2 berada pada kelompok usia lebih dari 60 tahun sebanyak 34 orang. Dalam penelitian Cantrill dan Wood (2003), angka kejadian diabetes melitus tipe 2 meningkat seiring dengan bertambahnya usia dan meningkatnya kejadian obesitas. Proses degeneratif dapat mempengaruhi kinerja hormon dalam mengatur proses reproduksi, metabolisme, serta memengaruhi berbagai fungsi tubuh lainnya. Penuaan mempengaruhi sensitivitas sel beta pankreas terhadap glukosa serta menghambat intake glukosa yang dimediasi insulin. Resistensi insulin pada penuaan terkait dengan kerusakan pada post reseptor (Triplit, et al, 2005).

\section{Jenis Kelamin}

Mayoritas responden pasien diabetes melitus tipe 2 berjenis kelamin perempuan sebanyak 53 pasien $(54,1 \%)$. Sementara untuk responden laki-laki sebanyak 45 pasien (45,9\%). Hal tersebut selaras dengan penelitian Rafika dkk (2011) yang memaparkan bahwa mayoritas penderita diabetes melitus tipe 2 adalah perempuan.

Penelitian-penelitian sebelumnya menunjukkan keberagaman hasil pada distribusi jenis kelamin namun 
tidak terdapat perbedaan jumlahnya tidak memperlihatkan hasil yang berbeda signifikan. Perempuan atau laki-laki samasama beresiko mengalami diabetes melitus tipe 2. Menurut American Diabetes Association, gender bukan merupakan faktor risiko munculnya diabetes melitus tipe 2. Di antaranya riwayat diabetes melitus, dyslipidemia, hipertensi, ras, dan obesitas (Anonim, 2006).

\section{Pendidikan}

Mayoritas responden berada pada tingkat pendidikan rendah yakni SMA, SMP, SD, dan tidak sekolah sebanyak 78 pasien $(79,6 \%)$. Sementara itu responden dengan tingkat pendidikan tinggi yakni S2, S1, D3, D2, dan D1 sebanyak 20 pasien (20,4\%). Hal tersebut selaras akan penelitian Goz, dkk., (2006) yang menyebutkan bahwa mayoritas responden berada pada tingkat pendidikan rendah.

\section{Pekerjaan}

Pekerjaan responden sebagian besar adalah pekerjaan tinggi yakni swasta, wiraswsta, serta PNS sebanyak 68 pasien $(69,4 \%)$, sementara untuk pasien dengan kategori pekerjaan rendah yakni pedagang, buruh, dan tidak bekerja sejumlah 30 pasien (30,6\%).

\section{Lama Menderita}

Berdasar tabel di bawah ini, terlihat bahwa mayoritas pasien sejumlah 57 pasien $(58,2 \%)$ menderita DM tipe 2 selama kurang 10 tahun. Serta pasien yang mengalami diabetes melitus tipe 2 melebihi 10 tahun sejumlah 41 pasien $(41,8 \%)$. Lamanya waktu menderita memperlihatkan lamanya pasien tersebut terkena diabetes melitus tipe 2 sejak ditegakkan diagnosis. Lama menderita penyakit diabetes melitus berkaitan dengan adanya risiko komplikasi. Factor utama pencetus komplikasi pada DM adalah durasi dan tingkat keparahan diabetes (Anonim, 2006).

Tabel 1. Gambaran Karakteristik Pasien Diabetes Melitus Tipe 2



Gambaran penggunaan terapi ADO yang diresepkan oleh dokter pada pasien DM tipe 2 di poliklinik penyakit dalam RSHD Kota Bengkulu dijabarkan dalam Tabel II. Mayoritas pasien yang mendapat terapi ADO tunggal yakni sulfonilurea 
sebanyak 10 pasien $(10,2 \%)$ dan metformin sebanyak 21 pasien $(21,4 \%)$. Obat kombinasi dua ADO yang paling banyak digunakan adalah metformin dan sulfoniurea sebanyak 48 pasien $(48,9 \%)$, kombinasi sulfonilurea dan akarbose sebanyak 7 pasien $(7,1 \%)$ dan kombinasi metformin dan akarbose sebanyak 6 pasien $(6,2 \%)$. Sementara penggunaan obat kombinasi tiga ADO yaitu akarbose, sulfonilurea, dan metformin sebanyak 6 pasien $(6,2 \%)$.

Metformin yang digunakan berupa obat generik, yakni metformin $850 \mathrm{mg}$ serta metformin 500 mg. Efek samping yang kerap timbul selama penggunaan metformin yakni nyeri abdomen, muntah, mual, dan diare (Zhai S, et al, 2016).

Gliclazide merupakan obat antidiabetik oral yang termasuk dalam golongan sulfonilurea generasi kedua. Gliclazide yang digunakan berupa obat branded yaitu glucodex ${ }^{\circledast}$ yang mengandung glikazide $80 \mathrm{mg}$. Antidiabetik oral lainnya yang digunakan yakni glimepiride dari golongan sulfonilurea generasi kedua. Efek samping yang sering ditemui pada pemakaian obat golongan sulfonilurea antara lain kolestasis, muntah, mual, priuritus, ruam, reaksi hematologi, dan hipoglikemia (Triplit et al, 2005).

Obat antidiabetik oral golongan penghambat alfa glkosidase yang digunakan adalah akarbose generik $50 \mathrm{mg}$ merupakan. Efek samping akarbose yaitu diare, flatulens, dan rasa tidak nyaman diperut (Soegondo, 2008).

Tabel 2. Pola Penggunaan ADO

$\begin{array}{lll}\text { Pola Penggunaan ADO } & \text { N } & \%\end{array}$

\begin{tabular}{lcc}
\hline Tunggal & & \\
Sulfonilurea & 10 & 10 \\
Metformin & & 21 \\
Kombinasi 2 ADO & 21 \\
Metformin+Akarbose & & 4 \\
Sulfonilurea+Akarbose & 6 & 6,2 \\
Metformin+Sulfonilurea & 7 & 7,1 \\
Kombinasi 3 ADO & 48 & 48 \\
Metformin+Sulfonilurea+Akarbos & 6 & 6,2 \\
e & & \\
Total & $\mathbf{9}$ & $\mathbf{1 0 0}$ \\
\hline
\end{tabular}

Keterangan: $\mathrm{N}=$ jumlah responden

\section{Kualitas Hidup}

\section{a. Berdasarkan Demografi Subyek}

Kualitas hidup dapat dinilai dari fungsi sosial dan fisik serta kesehatan mental dan fisik. Beberapa factor dari karakteristik subyek dan psikososial bisa mempengaruhi kualitas hidup, maka dari itu seharusnya dapat dikendalikan ketika membandingkan antar kelompok Rubin dan Peyrot, 2000). Instrumen penelitian yang digunakan untuk mengukur kualitas hidup pasien diabetes melitus adalah kuesioner DQLCTQ (Diabetic Quality of Life Clinical Trial Qessionnaire).

Karakteristik subyek penelitian meliputi usia, jenis kelamin, pendidikan, pekerjaan, dan lama menderita diabetes mellitus secara statistik tidak terdapat perbedaan yang signifikan terhadap kualitas hidup ( $p>0,05)$. Pada karakteristik usia, rata-rata skor kualitas hidup pasien yang berusia <60 tahun lebih tinggi dibandingkan dengan pasien yang berusia $>60$ tahun. Namun, setelah dianalisis secara statistk tidak terdapat perbedaan bermakna $p>0,05 \quad(p=0,155)$. Hasil penelitian ini selaras dengan penelitian 
Redekop, dkk., (2002) yang menyatakan bahwa usia yang lebih muda memiliki sikap yang cenderung positif dalam pandangan hidup daripada yang berusia tua. Pasien berusia $>60$ tahun, mempunyai kualitas hidup paling rendah dibanding yang lainnya, sementara kualitas hidup paling tinggi dirasakan pasien yang berusia di $<60$ tahun.

Pada karakteristik jenis kelamin, ratarata skor kualitas hidup perempuan lebih tinggi dibandingkan laki-laki. Namun hasil tersebut menunjukkan tidak terdapat perbedaan signifikan setelah dianalisis secara statistik $p>0,05(0,742)$. Penelitian ini tidak selaras dengan penelitian yang dilakukan Hartati (2003) dimana menjelaskan bahwa jenis kelamin laki-laki menunjukkan kualitas hidup yang lebih baik pada domain fungsi fisik, energi, kesehatan mental dan frekuensi gejala. Hal ini mungkin dikarenakan laki-laki lebih ikhlas menerima kondisi kesehatannya sehingga tidak terlalu banyak keluhan yang dirasakan. Laki-laki mempunyai sikap yang lebih positif dibanding perempuan pada semua dimensi sehingga dapat disimpulkan bahwa perbedaan jenis kelamin mempengaruhi kualitas hidup pasien diabetes (Grey, dkk., 2002).

Berdasarkan penelitian yang dilakukan oleh Hartati (2003) faktor pendidikan juga mempengaruhi kualitas hidup pasien diabetes yang menyebutkan pada pendidikan yang lebih tinggi memiliki kualitas hidup yang lebih baik. Hasil penelitian ini sesuai dengan penelitian sebelumnya yang dilakukan Hartati (2003) namun menunjukkan tidak ada perbedaan bermakna dari kualitas hidup pada faktor pendidkan $\mathrm{p}>0,05$ $(p=0,415)$. Penelitian ini menunjukkan bahwa kualitas hidup pada subyek penelitian dengan pekerjaan rendah lebih baik dibanding pasien dengan pekerjaan tinggi, namun tidak berbeda signifikan berdasarkan uji statistic $p>0,05(p=0,426)$.

Lamanya pasien menderita penyakit salah satu faktor yang mempengaruhi kualitas hidup pasien. Berdasarkan uji independent sample t-test tidak terdapat perbedaan secara bermakna $p>0,05$ $(p=0,067)$. Hasil penelitian ini sejalan dengan penelitian yang dilakukan oleh Redekop, dkk., dimana menjelaskan bahwa semakin lama durasi diabetes yang diderita oleh pasien semakin rendah kualitas hidup pasien tersebut. Pasien dengan durasi diabetes $<10$ tahun memiliki kualitas hidup tertinggi, sedangkan kualitas hidup terendah pada pasien dengan durasi diabetes $>10$ tahun (Grey, dkk., 2002).

Tabel 3. Kualitas Hidup Berdasarkan Karakteristik Subyek Penelitian

\begin{tabular}{ccc}
$\begin{array}{c}\text { Karakteristik } \\
\text { Subyek }\end{array}$ & $\mathbf{N}(\%)$ & $\begin{array}{c}\text { Rata-rata } \\
\text { kualitas } \\
\text { hidup }\end{array}$ \\
\hline
\end{tabular}

Usia

$\begin{array}{lccc}>60 \text { tahun } & 39 & & \\ <60 \text { tahun } & (39,8) & 97,5 \pm 15,6 & 0,155 \\ & 59 & 99,7 \pm 13,9 & \\ & (60,2) & \end{array}$

Jenis Kelamin

Perempuan

Laki-Laki

53
$(54,1)$
45

$99,3 \pm 14,8$

$98,2 \pm 14,4$

0,742

$(45,9)$

Pendidikan

Tinggi ( S2, S1,

D3, D2, D1)

20

$99,0 \pm 16,3$

0,415

Pendidikan 


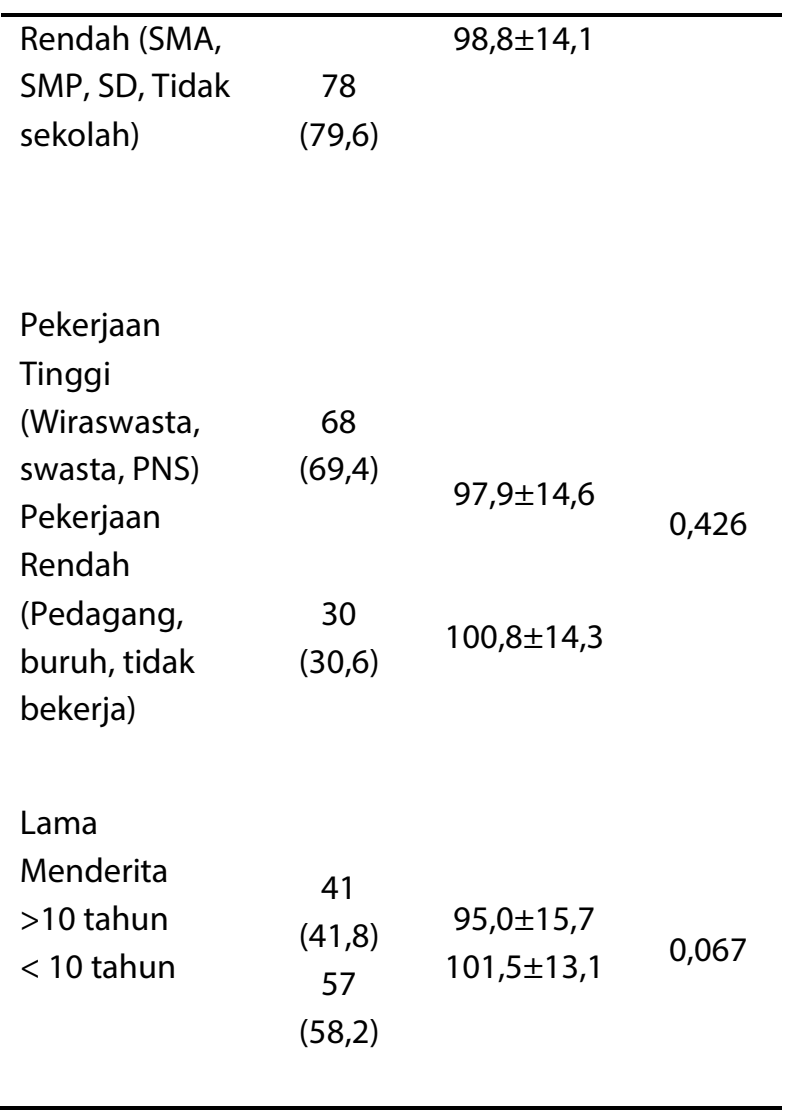

Keterangan: $\mathrm{N}=$ jumlah responden (\%)

\section{b. Berdasarkan Jenis Obat}

Pengukuran kualitas hidup pasien DM tipe 2 juga dinilai berdasarkan jenis terapi pengobatan antidiabetik oral yang digunakan yaitu golongan penghambat alfa glukosidase (akarbose), golongan sulfonilurea (glimepiride dan gliclazide), serta golongan biguanid (metformin). Rata-rata skor kualitas hidup pasien dengan akarbose, metformin, dan sulfonilurea masing-masing 61,0;61,3; dan 61,4. Berdasarkan uji Anova perbedaan kualitas hidup total antara ketifa jenis terapi pengobatan yang digunakan tidak ada perbedaan yang signifikan $p>0,05$ $(p=0,812)$.

Nilai rata-rata kualitas hidup pada kelompok pasien yang memperoleh terapi pengobatan golongan sulfonilurea yang tertinggi yakni pada domain fungsi fisik, tekanan kesehatan, kesehatan mental, efek pengobatan, dan kepuasan pengobatan dibandingkan kelompok yang memperoleh pengobatan dengan akarbose serta metformin. Namun untuk ketiga kelompok tersebut tidak terdapat perbedaan yang signifikan $p>0,05$ $(p=0,812)$. Untuk kelompok pasien dengan terapi pengobatan metformin, mempunyai rata-rata skor tertinggi pada domain energi daripada dua kelompok lainnya meskipun secara statistk tidak terdapat perbedaan $p>0,05 \quad(p=0,899)$. Pada kategori pasien yang mendapatkan antidiabetik oral akarbose diabndingkan dua kelompok lain memiliki skor yang paling tinggi pada domain kepuasan pribadi dan frekuensi gejala namun secara statistik tidak ada perbedaan signifikan $p>0,05(p=0,954 ; p=0,614)$.

Tabel 4. Kualitas Hidup Pada Terapi ADO Berdasarkan Jenis Obat yang Digunakan

\begin{tabular}{|c|c|c|c|c|}
\hline \multirow[b]{2}{*}{$\begin{array}{l}\text { Domain } \\
\text { Kualitas } \\
\text { Hidup }\end{array}$} & \multicolumn{3}{|c|}{ Jenis Obat** } & \multirow[b]{2}{*}{ P* } \\
\hline & $\begin{array}{c}\text { Metfor } \\
\text { min } \\
(n=181 \\
)\end{array}$ & $\begin{array}{c}\text { Sulfonil } \\
\text { urea } \\
(n=71)\end{array}$ & $\begin{array}{c}\text { Akarb } \\
\text { ose } \\
(n=21)\end{array}$ & \\
\hline $\begin{array}{l}\text { Fungsi } \\
\text { Fisik }\end{array}$ & $\begin{array}{c}69,9 \pm 4 \\
3\end{array}$ & $70,0 \pm 3,8$ & $\begin{array}{c}69,2 \pm 4 \\
4\end{array}$ & $\begin{array}{l}0,9 \\
00\end{array}$ \\
\hline Energi & $\begin{array}{c}69,7 \pm 4 \\
3\end{array}$ & $69,4 \pm 4,1$ & $\begin{array}{c}69,3 \pm 3 \\
8\end{array}$ & $\begin{array}{l}0,8 \\
99\end{array}$ \\
\hline $\begin{array}{l}\text { Tekanan } \\
\text { Kesehat } \\
\text { an }\end{array}$ & $\begin{array}{c}57,2 \pm 2 \\
0\end{array}$ & $57,5 \pm 1,8$ & $\begin{array}{c}57,2 \pm 1 \\
9\end{array}$ & $\begin{array}{l}0,6 \\
26\end{array}$ \\
\hline $\begin{array}{l}\text { Kesehat } \\
\text { an } \\
\text { Mental }\end{array}$ & $\begin{array}{c}57,2 \pm 2 \\
2\end{array}$ & $57,5 \pm 2,0$ & $\begin{array}{c}57,2 \pm 2 \\
7\end{array}$ & $\begin{array}{l}0,9 \\
43\end{array}$ \\
\hline $\begin{array}{l}\text { Kepuasa } \\
\text { n Pribadi } \\
\text { Kepuasa }\end{array}$ & $\begin{array}{c}56,0 \pm 2 \\
4\end{array}$ & $56,0 \pm 2,4$ & $\begin{array}{c}56,3 \pm 2 \\
7\end{array}$ & $\begin{array}{l}0,9 \\
54\end{array}$ \\
\hline $\begin{array}{l}\mathrm{n} \\
\text { Pengob } \\
\text { atan }\end{array}$ & $\begin{array}{c}60,9 \pm 1 \\
5\end{array}$ & $61,0 \pm 1,4$ & $\begin{array}{c}60,9 \pm 1 \\
4\end{array}$ & $\begin{array}{l}0,9 \\
26\end{array}$ \\
\hline $\begin{array}{l}\text { Efek } \\
\text { Pengob } \\
\text { atan }\end{array}$ & $\begin{array}{c}62,8 \pm 14 \\
, 4\end{array}$ & $\begin{array}{c}63,2 \pm 14 \\
7\end{array}$ & $\begin{array}{c}61,2 \pm 1 \\
7\end{array}$ & $\begin{array}{l}0,9 \\
25\end{array}$ \\
\hline
\end{tabular}




\begin{tabular}{lcccc}
\hline Frekuen & $56,8 \pm 1$, & \multirow{2}{*}{$56,9 \pm 1,7$} & $57,2 \pm 1$, & 0,6 \\
si Gejala & 7 & & 9 & 14 \\
Rata- & $61,3 \pm 4$, & $61,4 \pm 4,1$ & $61,0 \pm 2$, & 0,8 \\
rata QoL & 1 & & 5 & 12 \\
\hline
\end{tabular}

Keterangan: ${ }^{* *}$ subyek dapat memperoleh satu jenis ADO atau lebih

\section{c. Berdasarkan Pola Terapi}

Pengukuran kualitas hidup pasien diabetes melitus tipe 2 dapat dilihat dari jenis terapi pengobatan yang diberikan. Pada tabel $\mathrm{V}$ menunjukkan pasien yang mendapatkan terapi pengobatan antidiabetik oral tunggal lebih tinggi daripada pasien dengan terapi pengobatan kombinasi baik dua atau tiga obat antidiabetik oral. Namun tidak ada perbedaan secara signifikan dengan uji independent sample t-test $(p=0,134)$. Hal ini terjadi karena pasien dengan antidiabetik oral tunggal kadar glukosa darahnya terkendali dengan baik dan jarang timbul efek samping.

Pasien dengan kategori pengobatan antidiabetik oral tunggal memiliki nilai rerata kualitas hidup lebih tinggi hampir pada semua domain kecuali domain kesehatan mental dan kepuasan pribadi. Pada domain fungsi fisik, kelompok terapi pengobatan antidiabetik oral tunggal dapat melakukan aktivitas atau pekerjaan sehari-hari daripada kategori pengobatan antidiabetik oral kombinasi. Namun, setelah dinilai secara staitistik menunjukkan tidak terdapat perbedaan bermakna $p>0,05(p=0,129)$.

Pada domain energi kategori pasien yang mendapatkan terapi antidiabetik oral tunggal selalu berenergi dan bersemangat daripada kategori pengobatan antidiabetik oral kombinasi. Namun hasilnya tidak berbeda signifikan $p>0,05$ $(p=0,188)$.

Pada domain tekanan kesehatan kategori pasien yang mendapatkan terapi antidiabetik oral tunggal lebih ikhlas menghadapi kondisi kesehatannya, terus berjuang untuk menjalani pengobatan diabetes melitus tipe 2 dibandingkan kelompok terapi antidiabetik oral kombinasi. Walaupun perbedaan rerata nilai domain tekanan kesehatan dengan antidiabetik oral tunggal dibandingkan terapi antidiabetik oral kombnasi tidak terdapat perbedaan yang signifikan dengan nilai signifikansi $p>0,05(p=0,241)$.

Pada domain kesehatan mental kategori pengobatan antidiabetik oral kombinasi dibandingkan kelompok terapi antidiabetik oral tunggal merasa lebih tenang, damai dan bahagia serta tidak merasa cemas dan sedih terhadap penyakit diabetes melitus tipe 2. Tetapi tidak bermakna secara statistik dengan nilai signifikansi $p>0,05(0,875)$. Pada domain kepuasan pribadi, kategori pengobatan antidiabetik oral kombinasi lebih merasa puas dalam menjalani pengobatan diabetes melitus terkait kadar gula darah yang terkontrol, variasi menu makanan setiap hari dan tidak merasa terganggu dengan jadwal kontrol. Perbedaan ini dinilai tidak berbeda signifikan secara statistik $p>0,05(p=0,067)$.

Pada domain kepuasan pengobatan kategori pasien dengan terapi antidiabetik oral tunggal dibandingkan kategori pengobatan antidiabetik oral kombinasi merasa lebih puas terhadap pengobatan yang dijalani dan dapat mengendalikan diabetesnya. Meskipin perbedaan ini 
dinilai tidak bermakna secara statistik dengan nilai signifikansi $p>0,05(p=0,431)$. Pada domain efek pengobatan kategori pasien dengan pengobatan antidiabetik oral tunggal dibandingkan kategori pengobatan antidiabetik oral kombinasi lebih dapat menjalani diet, melakukan olahraga dan aktivitas sehari-hari. Namun tidak bermakna secara statistik $p>0,05$ $(p=0,219)$.

Pada domain frekuensi gejala kategori pasien dengan pengobatan antidiabetik oral tunggal hampir tidak pernah mengalami gejala yang biasa muncul pada penyakit diabetes melitus dibandingkan kelompok terapi antidiabetik oral kombinasi. Perbedaan nilai rerata domain frekuensi gejala pada pasien yang mendapat terapi antidiabetik oral tunggal dengan pasien yang mendapat terapi antidiabetik oral kombinasi dinilai oleh independent sample t-test tidak bermakna secara signifikan dengan nilai signifikansi $p>0,05(p=0,441)$.

Tabel 5. Kualitas Hidup Pada Terapi ADO Berdasarkan Pola Terapi

\begin{tabular}{|c|c|c|c|}
\hline \multirow{2}{*}{$\begin{array}{l}\text { Domain } \\
\text { Kualitas } \\
\text { Hidup }\end{array}$} & \multicolumn{2}{|c|}{ Jenis Terapi } & \multirow[b]{2}{*}{$\mathbf{P}$} \\
\hline & $\begin{array}{c}\text { Tunggal } \\
(n=31)\end{array}$ & $\begin{array}{c}\text { Kombinasi } \\
(n=67)\end{array}$ & \\
\hline $\begin{array}{l}\text { Efek } \\
\text { Pengobatan }\end{array}$ & $61,7 \pm 2,0$ & $53,1 \pm 16,2$ & 0,219 \\
\hline $\begin{array}{l}\text { Kepuasan } \\
\text { Pengobatan }\end{array}$ & $61,2 \pm 1,6$ & $60,9 \pm 14$ & 0,431 \\
\hline $\begin{array}{l}\text { Kepuasan } \\
\text { Pribadi }\end{array}$ & $66,5 \pm 1,8$ & $65,7 \pm 2,0$ & 0,067 \\
\hline $\begin{array}{l}\text { Kesehatan } \\
\text { Mental }\end{array}$ & $66,5 \pm 1,8$ & $65,7 \pm 2,2$ & 0,875 \\
\hline $\begin{array}{l}\text { Tekanan } \\
\text { Kesehatan }\end{array}$ & $57,7 \pm 2,1$ & $57,3 \pm 1,9$ & 0,241 \\
\hline $\begin{array}{l}\text { Frekuensi } \\
\text { Gejala }\end{array}$ & $57,1 \pm 2,0$ & $56,8 \pm 2,0$ & 0,441 \\
\hline Energi & $70,7 \pm 4,4$ & $69,4 \pm 4,2$ & 0,188 \\
\hline $\begin{array}{l}\text { Fungsi Fisik } \\
\text { Rata-rata }\end{array}$ & $71,2 \pm 3,9$ & $69,6 \pm 4,1$ & 0,129 \\
\hline $\begin{array}{l}\text { Kualitas } \\
\text { Hidup }\end{array}$ & $64,0 \pm 2,4$ & $62,3 \pm 4,3$ & 0,134 \\
\hline
\end{tabular}

\section{KESIMPULAN}

a. Berdasarkan karakteristik responden tidak terdapat perbedaan kualitas hidup terhadap usia, jenis kelamin, Pendidikan, pekerjaan, dan lama menderita diabetes melitus.

b. Berdasarkan jenis obat yang diresepkan untuk pasien DM tipe 2 di RSHD Kota Bengkulu, tidak terdapat perbedaan kualitas hidup terhadap pasien dengan terapi metformin, sulfonylurea, dan acarbose.

c. Berdasarkan jenis terapi yang dijalani pasien DM tipe 2 di RSHD Kota Bengkulu, tidak terdapat perbedaan kualitas hidup antara pasien dengan terapi ADO tunggal dan pasien dengan terapi ADO kombinasi.

\section{UCAPAN TERIMA KASIH}

Ucapan terimakasih penulis haturkan kepada Program Studi Sarjana Farmasi Universitas Bengkulu sebagai penyandang dana penelitian mandat S1 Farmasi sehingga penelitian ini dapat dilaksanakan dengan baik.

\section{DAFTAR PUSTAKA}

American Diabetes Association. Pharmacologic approache to glycemic treatment: Standards of medical care. 2018;41(1):S73-85. Doi: 10.2337/dc18-S008

Anonim, 2006, Pharmaceutical Care untuk Penyakit Diabetes Melitus, Direktorat Bina Farmasi Klinik dan Komunitas Departemen Kesehatan Repubik Indonesia, Jakarta

Cho NH, dkk.. 2018. IDF Diabetes Atlas: Global estimates of diabetes prevalence for 2017 and projections for 2045. Diabetes Res Clin Pract.138:271-81.doi: 10.1016/j.diabres.2018.02.023

DiPiro C. V., Schwinghammer T.L., Wells B.G., dan DiPiro J.T. 2016. Pharmacotherapy Handbook. Inggris: McGraw-Hill Education Companies. 
Facundo D., Nada G, Marcelo M. 2009. Mother risk update use of hypoglycemic drugs during lactation. Canadian Family Physician. 55:371-3.

Hartati, T., 2003, Kualitas Hidup Penderita DM Tipe 2: Perbandingan Antara Penderita Kadar Gula Terkendali dan Tidak Terkendali, Tesis, Program Pascasarjana, Universitas Gadjah Mada, Yogyakarta.

Isley, W.L., Reasner, C.A., \& Triplitt, C.L. 2005. Diabetes Melitus, dalam Dipiro, J.T., Talbert, R.I., Yee, G.C., Matzke G.R., Wells, B.G., \& Posey, L.M., (Eds.), Pharmacotherapy : A Pathophysiologic Aproach. USA:Appleton \& Lange. 1333-1364.

Kementerian Kesehatan RI. 2017. Profil Kesehatan Indonesia Tahun 2016. Jakarta: Kementerian Kesehatan Republik Indonesia.

Niessen, LW., Wolffenbuttei, BHR, Rutten, GEHM，Stolk, RP, Koopmanschap, MA, Redekop, WK. 2002. Heatlth-Related Quality of Life and Treatment Satisfaction in Dutch Patients With Type 2 Diabetes. Diab Care, 25: 458-463.

Patrick., D.L., Huster, W.J., Kotsanos, J.G., Shen, W., Mathias, S.D., Andrejaisch, C.M. 1999. Development and Validation of the Diabetes Quality of Life Clinical Trial Qyessionnaire. Medical Care. 37 (4) :45-66

Rubin, R.R.,\& Peyrot, M, 2000, Was will Right? Thoughts on The Interaction of Depression and Diabetes. Diabetes/metabolism reseacrh and review, 18 (3), 173-175.

Soegondo, S. 2004. Diagnosa dan Klasifikasi Diabetes Melitus Terkini. Jakarta:FKUI.

Supadmi, W, Perwitasari, D.A, Adikusuma, W, 2018, Evaluasi Kualitas Hidup Pasien Diabetes Melitus Tipe 2 Rumah Sakit Umum PKU Muhammadiyah Bantul, Prosiding "Simposium Nasional Peluang dan Tantangan Obat Tradisional dalam Pelayanan Kesehatan Formal"

Tri, M. Andayani., Jarir, A. Thobari., Rafika, M. Sari. 2011. Evaluasi Kualitas Hidup Pasien Diabetes Melitus Tipe 2 Yang Diterapi Rawat Jalan DenganAnti Diabetik Oral Di RSUP Dr. Sardjito. Jurnal Management dan Pelayanan Farmasi. 1 (1).

William, S., Susam, Chang, Yu., Boland, Elisabet, A., Grey, M. 2002. V. Personal and Family Factors Associated With Quality of Life in Aldolescents with Diabetes. Diabetes Care. 21 (6): 909-913.

Wood, J, Cantrill, JA. 2003. Diabetes Melitus, in walker, R.,Clinical Pharmacy and Therapeutics, $3^{\text {rd }}$ edition, UK: Churcill Livingstone.

Zhi J., Liang Z, Georgy A, Zhai S. 2016. Pharmacokinetic and pharmacodynamics drug interaction study of piragliatin, a sulfonylurea, glyburide, and a glucokinase activator in type 2 diabetic patients. Clin. Pharmacol. In Drug Development. 5(6):5526 